Available online at http://bajas.edu.iq

https://doi.org/10.37077/25200860.2021.34.sp1.6

Basrah Journal

College of Agriculture, University of Basrah

ISSN $1814-5868$

Basrah J. Agric. Sci., 34(Special Issue 1): 54-62, 2021

E-ISSN: 2520-0860

\title{
Biomass and Yield Estimation of MR219 and MR220 of Paddy Varieties using Terrestrial Laser Scanning Data
}

\author{
Zareen Zulkifli' $^{1}$, Siti Khairunniza-Bejo ${ }^{2 *}$, Farrah M. Muharam ${ }^{3}$, Ian Yule ${ }^{4}$, Reddy

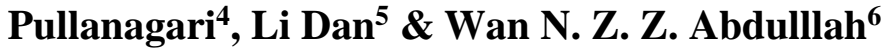 \\ ${ }^{1}$ Faculty of Plantation and Agrotechnology, Universiti Teknologi Mara Melaka, Kampus Jasin, \\ 77300 Merlimau Melaka, Malaysia, zareen.zulkifli@gmail.com \\ ${ }^{2}$ Department of Biological and Agricultural Engineering, Faculty of Engineering, Universiti Putra \\ Malaysia, 43400 Serdang, Selangor, Malaysia, skbejo@upm.edu.my \\ ${ }^{3}$ Department of Agriculture Technology, Faculty of Agriculture, Universiti Putra Malaysia, 43400 \\ Serdang, Selangor, Malaysia, farrahm@upm.edu.my \\ ${ }^{4}$ Institute of Agriculture and Environment, Massey University, Private Bag 11222, Palmerston \\ North, New Zealand, I.J.Yule@massey.ac.nz, P.R.Reddy@massey.ac.nz \\ ${ }^{5}$ Guangzhou Institute of Geography, No.100, Xianliezhong Road, Yuexiu District, Guangzhou, \\ China, lindan86@sina.com \\ ${ }^{6}$ Faculty of Agriculture and Food Science, UPM Bintulu Sarawak Campus, P.O Box 396, Nyabau \\ Road, 97008 Bintulu, Sarawak, Malaysia,wnzz@upm.edu.my \\ *Corresponding author email: skbejo@upm.edu.my \\ Received 19 September 2019; Accepted 11 March 2021; Available online 19 August 2021
}

\begin{abstract}
Rice (Oryza Sativa L.) is the main food source in Malaysia. Thus, to fulfill the needs, continuous rice production is required. Appropriate amount of nitrogen $(\mathrm{N})$ fertilizer is needed to ensure high production of rice. In this research, the effect of $\mathrm{N}$ to plant height, SPAD reading, biomass and yield were firstly studied. It was later followed by the estimation of biomass and yield using Terrestrial Laser Scanning (TLS) data. Different amount of N i.e. $0 \mathrm{~kg} / \mathrm{ha}, 85 \mathrm{~kg} / \mathrm{ha}, 170 \mathrm{~kg} / \mathrm{ha}$ and $250 \mathrm{~kg} / \mathrm{ha}$ were applied to MR 219 and MR 220 paddy. The 2-way ANOVA results showed that all parameters were significantly different at each $\mathrm{N}$ level. The highest reading was achieved at $250 \mathrm{~kg} / \mathrm{ha}$ of $\mathrm{N}$ level; $70.46 \mathrm{~cm}$ (plant height), 39.13 (SPAD reading), $927.29 \mathrm{~g} / \mathrm{m}^{2}$ (biomass) and $830.99 \mathrm{~g} / \mathrm{m}^{2}$ (grain yield) respectively. Therefore, these parameters can be used to indicate the level of input nitrogen at the plant. Later, the plant height calculated using developed Crop Surface Model (CSM) of the Terrestrial Laser Scanning (TLS) data was used to evaluate the biomass and grain yield of paddy. Results has shown that high correlations and regression were accomplished for CSM plant height and biomass $\left(\mathrm{R}^{2}=0.809\right)$. However, the results between CSM plant height and grain were lower $\left(R^{2}=0.582\right)$. In accordance with the outcome, biomass and yield were best estimated at 94 Day After Sowing (DAS). An estimation model for biomass and grain yield using linear equation was developed. Then a t-test was done to test the estimated and measured biomass and grain yield. The outcome showed that there was no significance difference between measured and estimated values. The values for both parameters were $1(\mathrm{p} \geq 0.05)$. Thus, it can be said that CSM plant height can be used to estimate biomass and grain yield.
\end{abstract}

Keywords: Biomass, Yield, Height, Phase shift, Laser scanner. 


\section{Zulkifli et al. / Basrah J. Agric. Sci., 34(Special Issue 1):54-62, 2021}

\section{Introduction}

Rice plant is an important plant for a significant portion of the world's residents especially in Malaysia. Rice is eaten routinely and forms a superior part of a standard diet for people and supplied a large fraction of the needs for energy-rich materials. It is also important for other nutrients intake as well.

Rice monitoring is essential for optimizing food security, to sustain environmental issues and to increase general economic prosperity. Some of the possible measures of plant growth used in monitoring are leaf area index (LAI), vegetation index, plant height and biomass. Plant height is the most direct measurement and can be used to identify the rice varieties, yield estimation and harvest planning, grain production management and grain handling and marketing (Sritarapipat \& Rakwatin, 2012; Gao et al., 2013) There are various researches has been done on the application of TLS in agricultural field. Lumme et al. (2008) investigated the utilization of laser scanners and laser point data in agriculture and precision farming. Faro laser scanner was used for growth height estimation and ear recognition for barley and wheat. The results showed that the TLS was a useful tool for growth height and grain yield estimation and could be used as precision farming tool in agriculture.

Lately, a Terrestrial Laser Scanning (TLS) technology has been introduced. This technology gives exact and dense 3D measurement of object. It was used in tree modelling to determine the canopy structure and leaf area using TLS technique by Riczu $e t$ al. (2011). A total of seven scans have been acquired using Leica Scan Station C10 laser scanner on two pear and one planted apple varieties. The tree parameters such as stem diameter, height, surface and volume have been estimated successfully. They have concluded that the laser scanning technology could be used to determine some characteristics of studied trees with fast and non-destructive method. In addition, Keightley \& Bawden (2010) in their research about grapevine biomass modelling using Tripod LIDAR have concluded that laser scanning technique gave encouraging results to be used correspondingly due to a highly linear relationship between vine volume and tissue mass.

In paddy-related studies, Tilly et al. (2014, 2015) used TLS based on a time of flight approach to monitor plant height on paddy fields by establishing crop surface models with $1 \mathrm{~cm}$ resolution. Subsequently the derived plant height was utilized to estimate paddy biomass. The technique used a Riegl VZ-1000 (Riegl, Austria) and gave strong coefficient of determination (0.91) between the TLS-derived and manually measured plant heights as well as the estimation of biomass based on the derived height, which illustrated an encouraging R2 value of 0.86 . The measurement of TLS made by Tilly et al. (2014, 2015), nevertheless, only concentrated on the early stages of rice paddy cultivation, which were from the stages of leaf development to stem elongation. Meanwhile, Zulkifli \& Khairunniza-Bejo (2015) used a phase shift TLS to monitor rice plant height at multiple growing stages. They reported that the monitoring of spatial and temporal pattern of the growth developed from CSM maps can be used. This has been supported by high coefficient of determination value, $(\mathrm{R} 2=$ 0.96). Therefore, the objective of this study was to analyse the effect of $\mathrm{N}$ to plant height, 
SPAD reading, biomass and yield; and to determine the rice yield using Terrestrial Laser Scanning method.

\section{Materials \& Methods}

\section{Data Collection}

The same plot of study area presented in Zulkifli \& Khairunniza-Bejo (2015) was used in this study. In this research, data collection of plant height, SPAD, biomass and grain yield were done manually and using terrestrial laser scanner.

\section{Manual Data Collection}

By using a measuring tape, three measurements of maximum plant heights were manually taken for each pot starting from soil surface in the pot to the tip of the tallest plant. Then, a SPAD-meter was used to measure $\mathrm{N}$ (leave greenness), as Gholizadeh et al. (2009; 2011) have reported that it is user friendly and provides data of the leaves' relative chlorophyll content. The measurements were taken from the youngest fully developed leaves at the centre top, middle and bottom. The average values were used to get the relative chlorophyll content. The measurement of rice plant height and SPAD reading was conducted at each stage.

Data of biomass and grain yield were collected during harvesting stage (109 DAS). The plants were put in sampling bag after been cut from the soil surface and any attached soil material were cleaned off. A total of 72 hours (2-3 days) were needed to dry the samples or until it reaches constant weight in the oven of $70^{\circ} \mathrm{C}$. To obtain the oven-dried weight of aboveground biomass $(\mathrm{g} / \mathrm{m} 2)$, the final ovendried weights were recorded instantly after taking them out from the oven.

As for the rice grain yield, the grains were threshed by hands after cutting all the panicles.
Then, the grains were leave sun-dried for 2 to 3 days or approximately $14 \%$ moisture content before being weighed $\left(\mathrm{g} \cdot \mathrm{m}^{-2}\right)$.

\section{Terrestrial Laser Scanner Measurement}

A faro laser scanner Focus 3D SX 130, version 6.1 (FARO Technologies, Inc., Florida, USA) was used during data acquisition to measure the height of the paddy as shown in fig. (1). The data collections were collected at every growth stage starting from 21 DAS until 94 DAS. Therefore, there were nine different dates of data acquisition. Table (1) shows the details on data acquisition. The plant height derived by the crop surface models with high spatial resolution of $1 \mathrm{~cm}$ as discussed in Zulkifli \& Khairunniza-Bejo (2015) were used to approximate biomass and grain yield.

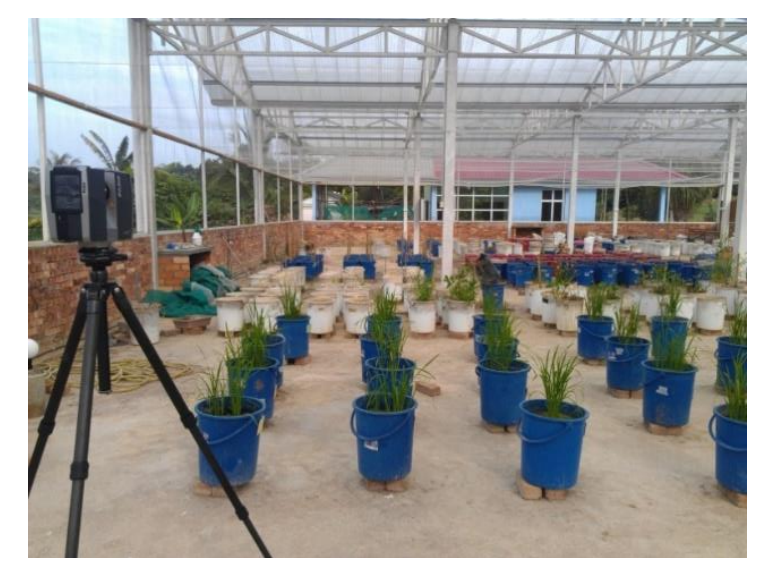

Fig. (1): Data acquisition using faro Laser Scanner.

Table (1): Details for data acquisition.

\begin{tabular}{ccc}
\hline Date & DAS & Stage \\
\hline 24 June 2014 & 21 & Early tillering \\
5 July 2014 & 32 & Tillering \\
14 July 2014 & 41 & Early booting \\
22 July 2014 & 49 & Booting \\
1 August 2014 & 58 & Panicle \\
& & initiation \\
12 August 2014 & 69 & Flowering \\
22 August 2014 & 80 & Milk grain \\
29 August 2014 & 87 & Dough grain
\end{tabular}


Zulkifli et al. / Basrah J. Agric. Sci., 34(Special Issue 1):54-62, 2021

5 September $\quad 94 \quad$ Mature grain 2014

Fig. (2) visualized an example of the developed Digital Surface Model (DSM) and Digital Elevation Model (DEM). So as to get the plants height derived from the Crop Surface Model (CSM), the DEM was subtracted from the DSM.

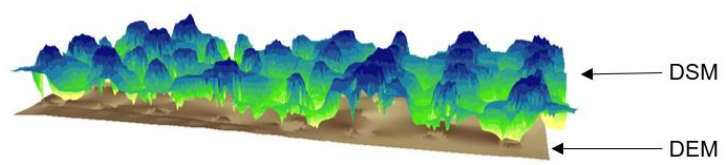

Fig. (2): Example of DSM (top) and DEM (bottom).

\section{Results \& Discussion}

This section first presents results on the effect of Nitrogen to all mentioned parameters earlier taken from the statistical analysis. It is then followed by the results of biomass and grain yield estimation using TLS data.

\section{Effect of Nitrogen to Plant Height, SPAD, Biomass and Grain Yield}

For the purpose of determining the significantly difference between all parameters at different $\mathrm{N}$ level, a mean comparison using Duncan Multiple Range Test (DMRT) was executed and the result was presented in table (2). All parameters were significantly affected at each different levels of $\mathrm{N}$ but not for the grain yield. Plant height shows high increment along with the increasing $\mathrm{N}$ rates, and the highest was recorded as $70.46 \mathrm{~cm}$ at $250 \mathrm{~kg} / \mathrm{ha}$ $\mathrm{N}$ while shortest was $60.07 \mathrm{~cm}$ in $0 \mathrm{~kg} / \mathrm{ha} \mathrm{N}$. Manzoor et al. (2006) have reported that the increment in plant height was because $\mathrm{N}$ has improved the vegetative growth.

Fig. (3) visualized the spatial and temporal development of the plant height for each date. The diversity in color intensity in the map shows the spatial differences. As the color becoming more intense, the plant heights were also increase. On the contrary, the changes in color from green to blue indicate the temporal development.
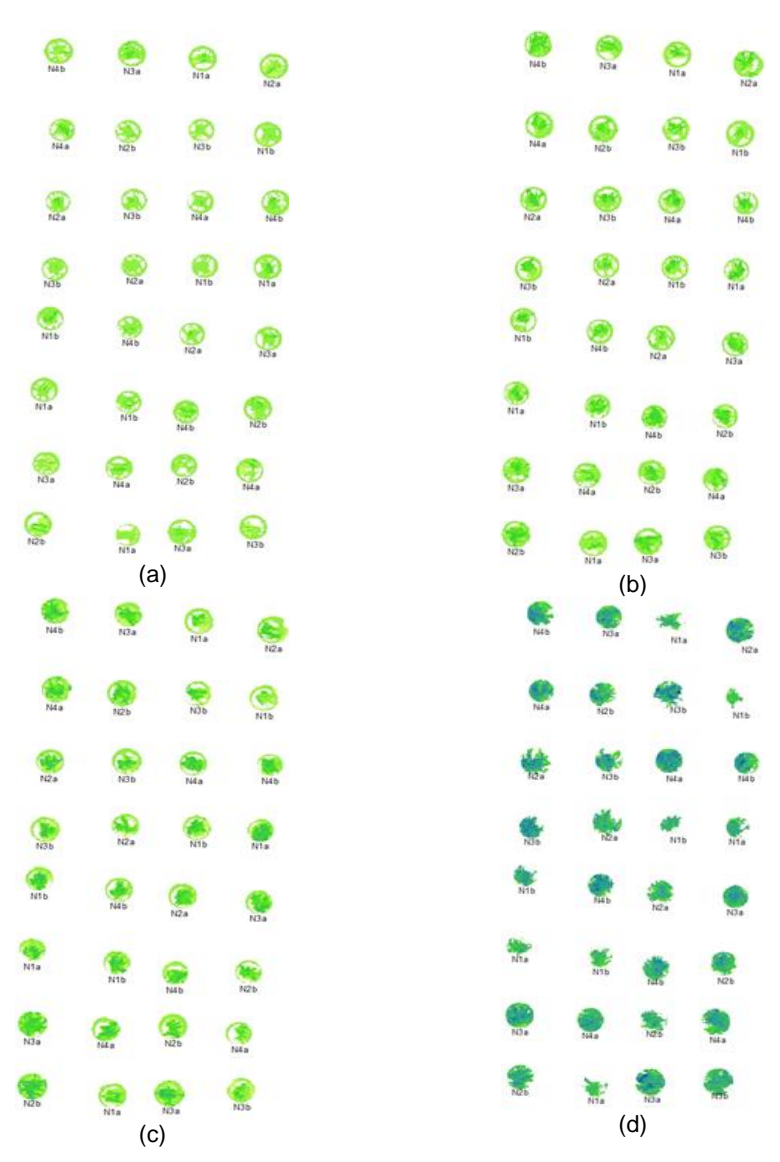

Plant height derived from CSM (cm)

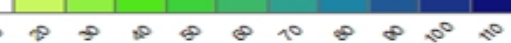

Note: $\mathrm{N} 1 *=0 \mathrm{~kg}$ ha- $1, \mathrm{~N} 2 *=85 \mathrm{~kg}$ ha- $1, \mathrm{~N} 3^{*}=170 \mathrm{~kg}$ ha- $1, \mathrm{~N} 4 *=250 \mathrm{~kg}$ ha- 1 ; where $*$ is the breed name i.e. $\mathrm{a}=$ MR219, $\mathrm{b}=$ MR220)

Fig. (3): Maps of plant height $(\mathrm{cm})$ derived from CSM for whole pots at each growth stages. (a) CSM at 21 DAS, (b) CSM at 32 DAS, (c) CSM at 41 DAS, (d) CSM at 58. DAS. 
Zulkifli et al. / Basrah J. Agric. Sci., 34(Special Issue 1):54-62, 2021

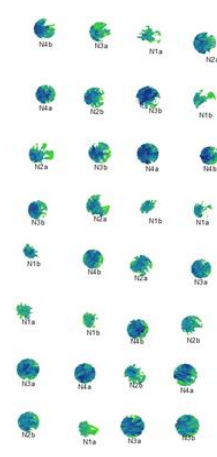

(e)

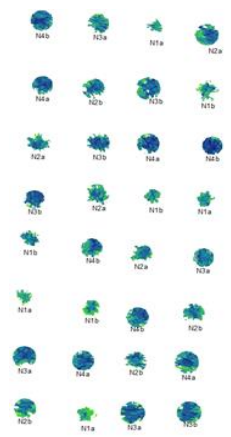

(f)

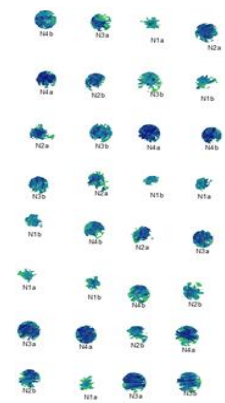

(g)

Plant height derived from CSM (cm)

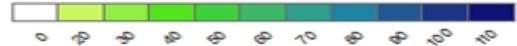

(Note: $\mathrm{N} 1 *=0 \mathrm{~kg}$ ha- $1, \mathrm{~N} 2 *=85 \mathrm{~kg}$ ha- $1, \mathrm{~N} 3 *=170$ $\mathrm{kg}$ ha- $1, \mathrm{~N} 4 *=250 \mathrm{~kg}$ ha- 1 ; where $*$ is the breed name i.e. $a=M R 219, b=M R 220$ )

Fig. (3): (cont.) Maps of plant height (cm) derived from CSM for whole pots at each

growth stages. (e) CSM at 80 DAS, (f) CSM at 87 DAS, (g) CSM at 94 DAS.

SPAD reading and biomass showed similar trend where the highest reading was recorded at $250 \mathrm{~kg} \cdot \mathrm{ha}^{-1} \mathrm{~N}$ with 39.13 and $927.29 \mathrm{~g} \cdot \mathrm{m}^{-2}$ respectively. This has been supported by other studies done by Lampayan et al. (2010), Shibu et al. (2010) and Azarpour et al. (2014).

As for grain yield, the lowest was recorded at zero $\mathrm{N}$ level $(360.92 \mathrm{~g} / \mathrm{m} 2)$ and it increased enormously at $85 \mathrm{~kg} / \mathrm{ha}$ of $\mathrm{N}(651.41 \mathrm{~g} / \mathrm{m} 2)$, $170 \mathrm{~kg} / \mathrm{ha}(772.89 \mathrm{~g} / \mathrm{m} 2)$ and $250 \mathrm{~kg} / \mathrm{ha}$ $(830.99 \mathrm{~g} / \mathrm{m} 2)$. Nevertheless, between 85 $\mathrm{kg} / \mathrm{ha}, 170 \mathrm{~kg} / \mathrm{ha}$ and $250 \mathrm{~kg} / \mathrm{ha}$ of $\mathrm{N}$ level there was not much different of grain yield. Increment of $\mathrm{N}$ level have caused the increment in grain yield as well due to the better uptake of $\mathrm{N}$ which assists to higher dry matter build-up and its translocation to their sink (Dalal \& Dixit, 1987). Marazi et al. (1993); Dixit \& Patro (1994), Daniel \& Wahab (1994), Bali et al. (1995) and Meena et al. (2003) have reported the same outputs.

Table (2): Duncan analysis for plant height, SPAD, biomass and grain yield at different $\mathrm{N}$ level.

\begin{tabular}{ccccc}
\hline N level & $\begin{array}{c}\text { Plant Height } \\
(\mathrm{cm})\end{array}$ & SPAD & $\begin{array}{c}\text { Biomass } \\
\left(\mathrm{g} / \mathrm{m}^{2}\right)\end{array}$ & $\begin{array}{c}\text { Grain Yield } \\
\left(\mathrm{g} / \mathrm{m}^{2}\right)\end{array}$ \\
\hline 0 & $60.07^{\mathrm{a}}$ & $31.71^{\mathrm{a}}$ & $307.04^{\mathrm{a}}$ & $360.92^{\mathrm{a}}$ \\
85 & $65.27^{\mathrm{b}}$ & $36.76^{\mathrm{b}}$ & $560.92^{\mathrm{b}}$ & $651.41^{\mathrm{b}}$ \\
170 & $68.23^{\mathrm{c}}$ & $37.60^{\mathrm{c}}$ & $703.35^{\mathrm{c}}$ & $772.89^{\mathrm{b}}$ \\
250 & $70.46^{\mathrm{d}}$ & $39.13^{\mathrm{d}}$ & $927.29^{\mathrm{d}}$ & $830.99^{\mathrm{b}}$ \\
\hline
\end{tabular}

Note: Mean values having same letter do not differ significantly at $5 \%$ level of probability

A correlation and regression analyses were done to quantify the association between all components and to identify the relationship between correlated components. The results for correlation were presented in table (3). Based on table (3), all components exhibited a positive and significant association between them. Plant height registered a positive and strong correlation to SPAD $(\mathrm{R}=0.857)$ and a bit lower compared to biomass $(\mathrm{R}=0.794)$ and grain yield $(\mathrm{R}=0.634)$.

\section{Estimating biomass and grain yield of paddy using TLS data}

Another statistical analysis was done by using plant height derived from CSM to discover whether TLS can be used to estimate the biomass and grain yield. Table (4) shows the 
results of correlation analysis. Based on the table, all components showed positive and significant relationship $(\mathrm{p} \leq 0.01)$. The coefficients were higher for CSM plant height with biomass $(\mathrm{R}=0.843)$ compared to CSM plant heights and grain yield $(\mathrm{R}=0.718)$. It also shows that grain yield was positively and strongly correlated to biomass $(\mathrm{R}=0.798)$ and this has been supported by Ntanos \& Koutroubas (2002).
For details on their relationship, regression analysis was done at every stage. Table (5) shows the summary of regression analysis. Good coefficient of determination between CSM plant height with biomass $(\mathrm{R} 2=0.809)$ and grain yield $(\mathrm{R} 2=0.582)$ were achieved at 94 DAS. The result of biomass was almost similar to the result of Tilly et al. (2014) in their research about biomass estimation using TLS scanner in rice field $(\mathrm{R} 2=0.876)$.

Table (3): Correlation analysis between plant heights, SPAD reading, biomass and grain yield.

\begin{tabular}{|c|c|c|c|}
\hline & SPAD & $\begin{array}{c}\text { Biomass } \\
\left(\mathrm{g} / \mathrm{m}^{2}\right)\end{array}$ & $\begin{array}{c}\text { Grain } \\
\text { yield } \\
\left(\mathrm{g} / \mathrm{m}^{2}\right)\end{array}$ \\
\hline Plant Height (cm) & $.857^{\star \star}$ & $.794^{\star \star}$ & $.634^{\star \star}$ \\
\hline SPAD & & $.748^{\star \star}$ & $.630^{\star \star}$ \\
\hline Biomass $\left(\mathrm{g} / \mathrm{m}^{2}\right)$ & & & $.798^{* \star}$ \\
\hline Grain Yield $\left(\mathrm{g} / \mathrm{m}^{2}\right)$ & & & \\
\hline
\end{tabular}

** Correlation is significant at the 0.01 level (2-tailed).

Table (4): Correlation analysis between CSM plant heights, biomass and grain yield.

\begin{tabular}{lcc}
\hline & $\begin{array}{c}\text { Biomass } \\
\left(\mathrm{g} / \mathrm{m}^{2}\right)\end{array}$ & $\begin{array}{c}\text { Grain } \\
\text { yield } \\
\left(\mathrm{g} / \mathrm{m}^{2}\right)\end{array}$ \\
\hline CSM Plant Height $(\mathrm{cm})$ &. $\mathbf{8 4 3}$ &. $\mathbf{7 1 8 ^ { \star * }}$ \\
Biomass $\left(\mathrm{g} / \mathrm{m}^{2}\right)$ & &. $\mathbf{7 9 8 ^ { \star * }}$ \\
Grain Yield $\left(\mathrm{g} / \mathrm{m}^{2}\right)$ & & \\
\hline
\end{tabular}

Table (5): Summary of regression analysis between all parameters at different growth stage (R2).

\begin{tabular}{|l|c|c|c|c|c|c|c|}
\hline & 21 & 32 & 41 & 58 & 80 & 87 & 94 \\
& DAS & DAS & DAS & DAS & DAS & DAS & DAS \\
\hline CSM and Biomass & 0.222 & 0.063 & 0.067 & 0.351 & 0.638 & 0.525 & 0.809 \\
\hline CSM and Grain Yield & 0.101 & 0.083 & 0.058 & 0.254 & 0.407 & 0.469 & 0.582 \\
\hline
\end{tabular}

The best linear regression analysis for CSM plant height with biomass and yield was presented in fig. (4) and fig. (5), respectively. The $\mathrm{R} 2$ values are increasing starting from 41 DAS which is early booting stage. During the first two stages, the plants were too small to present the significant growth and thus not suitable for the biomass and yield prediction. When the plants are growing, the biomass are also keeps increasing even when it reaches the 
heading stages where the height is remaining with no changes. More meaningful information comes from measurements taken from stem elongation to heading stage and this indicated that they are varies in the relationship between the CSM plant height with biomass and yield.

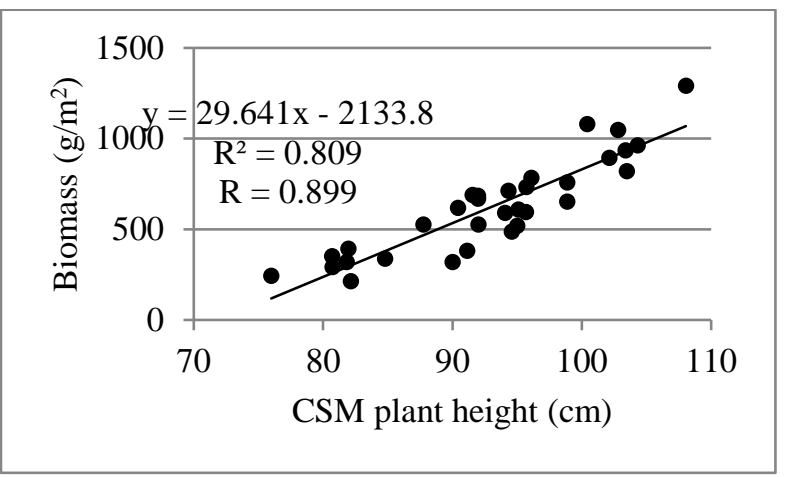

Fig. (4): Regression analysis between CSM plant height and biomass.

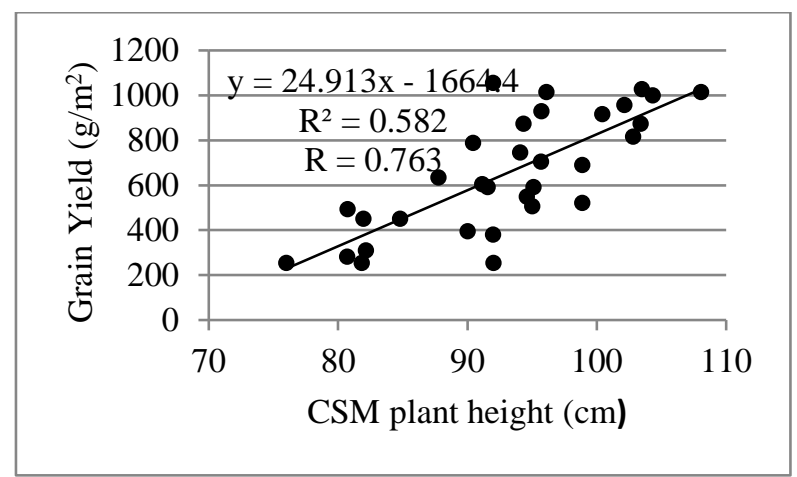

Fig. (5): Regression analysis between CSM plant height and grain yield.

Linear equation model produced from this analysis were then used to estimate the biomass and grain yield based on the CSM plant height. The equation models were as follows where $(\mathrm{x})$ is CSM plant height:

$$
\begin{array}{ll}
\text { Biomass }=29.641 \mathrm{x}-2133.8 & \text { Equation } 1 \\
\text { Grain yield }=24.913 \mathrm{x}-1664.4 & \text { Equation 2 }
\end{array}
$$

An independent t-test was carried out to assess if measured mean of biomass and grain yield were significantly different from estimated mean. Table (6) illustrates the result of t-test. No significant different between the two values, $t(62)=0, p=1.0 \geq 0.05$ for both biomass and grain yield have been reported.

For that reason, it suggests that the linear equation model produced from regression analysis was good enough. In addition, biomass and grain yield can also be projected using CSM plant height. This has been supported by studies done by Confalonieri et al. (2011). They mentioned that plant height as one of the main factors to estimate grain yield.

Table (6): t-test between measured and estimated biomass and grain yield.

\begin{tabular}{llcccccc}
\hline & & $\mathrm{N}$ & Mean & SD & $\mathrm{t}$ & $\mathrm{df}$ & $\begin{array}{c}\text { Sig } \\
\text { (2-tailed) }\end{array}$ \\
\hline Biomass & Measured & 32 & 624.65 & 264.02 & .00 & 62 & 1.0 \\
& Estimated & 32 & 624.62 & 237.41 & & & \\
Grain Yield & Measured & 32 & 654.05 & 261.55 & .00 & 62 & 1.0 \\
& Estimated & 32 & 654.03 & 199.54 & & & \\
\hline
\end{tabular}

\section{Conclusions}

The increment of $\mathrm{N}$ level does affect all measured parameters which they were also increased. This was because $\mathrm{N}$ promote exponential growth and increased the height which caused to increment in biomass and grain yield as well. The highest plant height $(70.46 \mathrm{~cm})$, SPAD reading (39.13), biomass $\left(927.29\right.$ g. $\left.\mathrm{m}^{-2}\right)$ and grain yield $\left(830.99 \mathrm{~m}^{-2}\right)$ 


\section{Zulkifli et al. / Basrah J. Agric. Sci., 34(Special Issue 1):54-62, 2021}

were recorded at $250 \mathrm{~kg} \cdot \mathrm{ha}^{-1}$ of $\mathrm{N}$ level. TLS also can be used to estimate biomass and grain yield. The CSM plant height was strongly correlated to biomass $(\mathrm{R}=0.899, \mathrm{R} 2=0.809)$ compared to grain yield $(\mathrm{R}=0.763, \mathrm{R} 2=$ 0.582 ) at 94 DAS. Linear equations produced from regression analysis were used to estimate biomass and grain yield from CSM plant height. A t-test analysis was accomplished to distinguish the result between measured and estimated biomass and grain yield, and the result showed that there was no significant different. To sum up, TLS can be used to estimate plant height, biomass and grain yield. This method as well can avoid damaged to samples.

\section{References}

Azarpour, E., Moraditochaee, M., \& Bozorgi, H. R. (2014). Effect of nitrogen fertilizer management on growth analysis of rice cultivars. International Journal of Biosciences, 4, 35-47. https://doi.org/10.12692/ijb/4.5.35-47

Bali, A. S., Siddique, M., Ganai, B. A., Khan, H. V., Singh, K. N., \& Bali. A. S. (1995). Response of rice (Oryza sativa) genotypes to nitrogen levels under transplanted conditions in Kashmir valley. Indian Journal of Agronomy; 40, 35-37.

Confalonieri, R., Bregaglio, S., Rosenmund, A.S., Acutis, M., \& Savin, I. (2011). A model for simulating the height of rice plants. European Journal of Agronomy, 34, 20-25.

Dalal, P. K., \& Dixit, L. (1987). Response of medium duration rice varieties to levels of nitrogen. Indian Journal of Agronomy, 32, 286-287.

Daniel, K. V., \& Wahab, K. (1994). Levels and time of nitrogen in semi dry rice. Madras Agriculture Journal, 81, 357-358.

Dixit, U. C., \& Patro N. (1994). Effect of NPK levels, zinc and plant density on yield attributes and yield of summer rice. Environment and Ecology, 12, 72-74.

Gholizadeh, A., Amin, M. S. M., Anuar, A. R., \& Aimrun, W. (2009). Evaluation of leaf total nitrogen content for nitrogen management in a Malaysian paddy field by using soil plant analysis development chlorophyll meter. American Journal of Agricultural and Biological Sciences, 4, 278-282. https://doi.org/ 10.3844/ajabssp.2009.278.282.

Gholizadeh, A., Amin, M., Soom, M., Rahim, A. A., \& Wayayok, A. (2011). Using soil plant analysis development chlorophyll meter for two growth stages to assess grain yield of Malaysian rice (Oryza sativa). American Journal of Agricultural and Biological Sciences, 6, 209-213, https://agris.fao.org/agrissearch/search.do?recordID=DJ2012079615

Gao, S., Niu, Z., Huang, N., \& Hou, X. (2013). Estimating the Leaf Area Index, height and biomass of maize using HJ-1 and RADARSAT-2. International Journal of Applied Earth Observation and Geoinformation, 24, 1-8. https://doi.org/10.1016/j.jag.2013.02.002.

Keightley, K. E., \& Bawden, G. W. (2010). 3D volumetric modelling of grapevine biomass using Tripod LiDAR. Computers and Electronics in Agriculture, $\quad 74, \quad 305-312$. https://doi.org/10.1016/j.compag.2010.09.005.

Lumme, J., Karjalainen, M., Kaartinen, H., Kukko, A., Hyyppä, J., Hyyppä, H., Jaakkola, A., \& Kleemola, J., (2008). Terrestrial laser scanning of agricultural crops. In: The International Achieves of the Photogrammetry, Remote Sensing and Spatial Information Sciences, 37, 563-566. https://citeseerx.ist.psu.edu/viewdoc/download?doi $=10.1 .1 .588 .908 \&$ rep $=$ rep $1 \&$ type $=$ pdf

Lampayan, R. M., Bouman, B. A. M., Dios, J. L. D., Espiritu, A. J., Soriano, J. B., \& Lactaoen A. T. (2010). Yield of aerobic rice in rain fed lowlands of the Philippines as affected by nitrogen management and row spacing. Journal of Field Crops Research, 116 , 165-174. https://doi.org/10.1016/j.fcr.2009.12.007

Manzoor, Z., Awan, T. H., Safdar, M. E., Ali, R. I., Ashraf, M. M., \& Ahmad, M. (2006). Effect of nitrogen levels on yield and yield components of basmati. Journal of Agriculture Research, 44, 115120 .

https://apply.jar.punjab.gov.pk/upload/1374662085 _85_Microsoft_Word_-_115-121.pdf

Marazi, A. R., Khan, G.M., Singh, K. H. \& Bali A. S., (1993). Response of rice (Oryza sativa) to different Nitrogen levels and water regimes in Kashmir Valley. Indian Journal of Agricultural Sciences. 63, 


\section{Zulkifli et al. / Basrah J. Agric. Sci., 34(Special Issue 1):54-62, 2021}

726-727.

https://agris.fao.org/agrissearch/search.do?recordID=IN9400011

Meena, S. L., Surendra. S., \& Shivay Y.S. (2003). Response of hybrid rice (Oryza sativa) to nitrogen and potassium application in sandy clay loam soils. Indian Journal of Agricultural Science, 73, 8-11.

http://scinet.dost.gov.ph/union/ShowSearchResult.php?

Ntanos D. A., \& Koutroubas S. D. (2002). Dry matter and $\mathrm{N}$ accumulation and translocation for Indica and Japonica rice under Mediterranean conditions. Field Crops Research, 74, 93-101. https://doi.org/10.1016/S0378- 4290(01)00203-9.

Riczu, P., Tamas, J., Nagy, A., Forian, T., Nagy, G., \& Jancso, T., (2011). 3D laser scanning and modeling of single trees in Karcag research center. Analele Universitatii din Oradea, Fascicula: Protectia Mediului, 17, 277-284.

http://protmed.uoradea.ro/facultate/anale/protectia_me diului/2011B/hor/10.\%20Riczu\%20Peter.pdf

Shibu, M. E., Leffelaar P.A., Van Keulen, H, \& Aggarwal, P. K., (2010). A simulation model for nitrogen-limited situations: Application to rice. European Journal of Agronomy, 32, 255-271. https://doi.org/10.1016/j.eja.2010.01.003

Sritarapipat, T., \& Rakwatin, P. (2012). Rice crop height monitoring using field server and digital image analysis. The 33th Asian Conference on Remote Sensing, 623-627. https://a-a-rs.org/proceeding/ACRS2012/Proceeding\%20ACRS \%202012/Technical\%20Sessions/C2\%20Algorithm $\% 20(5) / C 2-2 . p d f$

Tilly, N., Hoffmeister, D., Cao, Q., Huang, S., LenzWiedemann, V., Miao, Y., \& Bareth, G., (2014). Multitemporal crop surface models: accurate plant height measurement and biomass estimation with terrestrial laser scanning in paddy rice. Journal of Applied Remote Sensing, 8, 083671-083671. https://doi.org/10.1117/1.JRS.8.083671.

Tilly, N., Hoffmeister, D., Cao, Q., Lenz-Wiedemann, V., Miao, Y., Bareth, G. (2015). Transferability of models for estimating paddy rice biomass from spatial plant height data. Agriculture, 5, 538-560. https://doi.org/10.3390/agriculture5030538

Zulkifli, Z., \& Khairunniza-Bejo, S. (2015). Paddy growth monitoring using terrestrial laser scanner. Australian Journal of Basic and Applied Sciences, 9, 90-96.

https://www.semanticscholar.org/paper/PaddyGrowth-Monitoring-Using-Terrestrial-LaserZulkifli-KhairunnizaBejo/d8b51db449ce65fe870fe44d342584b8fdf07b7 3 